\title{
Mikä onkaan suhteeni brändeihin?
}

Hanna Lehtimäki \& Juha Suoranta (toim. 2006). Kasvattajan brändikirja. Finn-Lectura; Naomi Klein (2001). No logo. WSOY; Alissa Quart (2003). Brändätyt. Like.

\section{Kanadalainen journalisti Na- omi Klein puuttuu suuryritysten ylivaltaan teoksessaan No logo ja tarkastelee brändejä globaa- lina ilmiönä, kun taas Alissa Quart syventyy kirjassaan Brän- dätyt kriittisesti siihen, mitkä vaikutukset kaupallistuneella kulttuurilla on lasten ja nuorten kehitykselle. Hän näkee tässä ajassa elävät lapset brändätty- nä sukupolvena.}

Kasvattajan brändikirja jatkaa edellä mainittujen teosten viitoittamaa tietä ja haastaa lukijat mielenkiintoiselle matkalle brändien maailmaan. Kasvattajan brändikirja on artikkelikokoelma kaikille brändeistä ja niiden ymmärtämisestä kiinnostuneille lukijoille.

Kirjan artikkelit peilaavat todellisuutta brändien keskellä elävästä jälkimodernin yhteiskunnan kansalaisesta. Uusliberalistisessa markkinataloudessa elävät kansalaiset sosiaalistuvat kuluttajiksi jo lapsesta lähtien. Brändit ovat merkkituotteita, mielikuvia, tarinoita, arvoja ja elämäntapoja. Ne voidaan nähdä kapitalistisen yhteiskunnan uskontona, jolle pysytään uskollisena ja jonka nimeen vannotaan. Teos tarkastelee brändejä laajasti yksilö- ja yhteisötasolla ja yleisesti kulttuurisena ilmiönä. Teos on jaettu viiteen teemaan: brändien käyttö, brändit ja digitaalisuus, brändien rakentaminen, brändit ja kult- tuuri sekä kulttuurinen häirintä ja brändien haltuunotto.

Brändien käyttöä käsitellään kolmessa artikkelissa. Minna Autiokirjoittaa suomalaislasten ja -nuorten kasvusta kuluttajaksi brändien maailmassa. Terhi-Anna Wilska tarkastelee sitä, miten sukupuoli määrittää lasten ja nuorten kulutusta ja miten lapset ja nuoret kasvavat nais- ja mieskuluttajuuteen perheen ja yhteiskunnan sosialisaation kautta. Pekka Mattila laajentaa näkökulmaa brändien yhteisölliseen tehtävään tarkastellen sitä Pierre Bourdien pääoman teorian viitekehyksestä käsin.

Brändejä ja digitaalisuutta tarkastellaan kahden artikkelin verran. Sonja Kangaskäsittelee verkkobrändejä ja verkkoyhteisöön osallistuvien roolia brändin rakentajina ja muokkaajina. Heidi Keso, Hanna Lehtimäkija Tarja Pietiläinen kirjoittavat verkkobrändin luomisesta käyttäen tapausesimerkkinä virtuaaliyhteisö Sooda.comin kehitystä.

Brändien rakentuminen kappale sisältää kolme artikkelia. Aki-Mauri Huhtinen syventyy sodan brändäämiseen. Artikkeli on kuvaus siitä, miten sota tuotteistuu mediassa ja aikamme kulttuurissa. Johanna Kujala ja Elina Kivi kirjoittavat vastuullisesta brändistä ja sen rakentumisesta. Marjo Vuorikosken artikkeli paneutuu siihen, miten brändit näkyvät koulumaailmassa ja miten niiden mukana tuomat arvot ja elämäntavat ovat ristiriidassa koulun vallitsevan tilan kanssa.

Brändit ja kulttuuri -osioon on sisällytetty kolme artikkelia. Jussi Ojajärvi kirjoittaa siitä, miten brändit ovat esillä suomalaisessa kertomakirjallisuudessa, Atte Oksanen ja Sari Näre tosi-tv:stä ja moraalin brändäämisestä sekä Tarja RautiainenKeskustalo tunteiden brändäämisestä esimerkkinä Idols-ilmiö.

Kirjan päättävässä "Kulttuurinen häirintä ja brändien haltuunotto" -osiossa Reijo Kupiainen käsittelee muun muassa kulttuurinhäirintää sekä Mika Hannulan ja Juha Suorannan artikkeli katutaidetta ja brändien lukutaitoa.

Kasvattajan brändikirja on tärkeä ja ajankohtainen teos, jonka artikkelit tarkastelevat brändejä monipuolisesti ja mielenkiintoisesti. Tieteelliset artikkelit tarjoavat uusia näkökulmia ja ajatuksia, mutta eivät syyllisty moralisointiin. Parhaimmillaan artikkelit tarjoavat eväitä informaatioyhteiskunnan ymmärtämiseen ja sen kriittiseen tarkasteluun.

Brändit heijastavat elettävää aikaa. Ne muuttavat ja muokkaavat elettävää todellisuutta.

Artikkelit houkuttelevat lukijan pohtimaan henkilökohtaista suhdetta brändeihin ja niiden paikkaa omassa elämässä. Artikkeleiden loppuun lisätyt pohdittavaa-osiot syventävät käsiteltyä teemaa ja tarjoavat esimerkiksi opettajille lisävirikkeitä aiheen käsittelyyn.

JANI SIIRILÄ 